\title{
Chronic calcified subdural haematoma found after presentation of symptomatic glioma
}

\author{
Zoe Wing-Yan Chan, ${ }^{1}$ Pasquale Gallo ${ }^{2}$
}

${ }^{1}$ Neurosurgery, Western General Hospital, Edinburgh, UK ${ }^{2}$ Neurosugery, Western General Hospital, Edinburgh, UK

\section{Correspondence to} Dr Zoe Wing-Yan Chan, zoe17chan@googlemail.com

Accepted 25 May 2018

\section{DESCRIPTION}

A patient with neurofibromatosis 1 and childhood ventriculoperitoneal (VP) shunt insertion for hydrocephalus presented with 4 weeks of shortterm and working memory impairment. Apart from right-hand tremor, he denied headache, visual changes, weakness and dyscoordination. A CT head showed a right-sided subdural lesion with $22 \mathrm{~mm}$ midline shift. The MRI head showed a right inferior-frontal enhancing mass suspicious of high-grade glioma and right extensively calcified subdural extra-axial collection, with mixed heterogeneous predominantly T1-hyperintense contents (figure 1A).

$\mathrm{He}$ underwent right fronto-temporo-parietal craniotomy with chronic calcified subdural haematoma evacuation, right frontal mass resection plus duraplasty (figure 2). A postoperative MRI showed more than $90 \%$ debulking of the enhancing tumour (glioblastoma, WHO grade IV) and successful subdural evacuation (figure 1B). He received concurrent chemoradiotherapy and was well 4 months after surgery. Unfortunately, he developed recurrent seizures 11 months after his operation and follow-up MRI showed increased enhancement suggesting tumour regrowth. Repeat MRI following further tumour debulking showed rapid glioblastoma progression and he was not for further surgical intervention. He passed away 12 months after his initial diagnosis.

The glioma is likely responsible for his initial symptoms, but the coincidental calcified chronic subdural haematoma was striking. Non-traumatic subdural haematomas are recognised complications of VP shunt overdrainage, but calcification occurs in only $0.3 \%-2.7 \%$ of cases. ${ }^{12}$ If it were not for

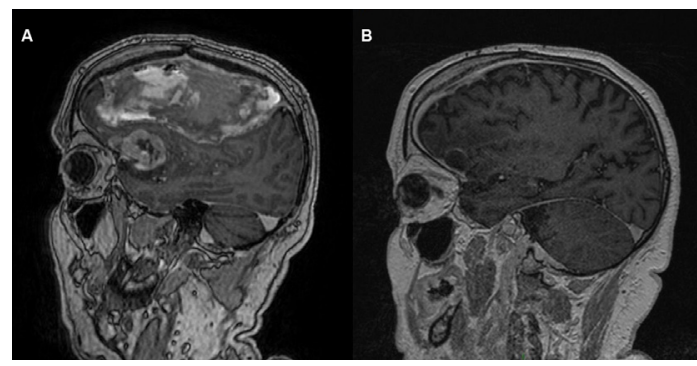

Figure 1 (A) Preoperative MRI shows a right inferior frontal mass suspicious of high-grade glioma and the extra-axial collection with mixed heterogeneous predominantly T1-hyperintense contents, and extensive calcification. (B) Postoperative MRI showing more than $90 \%$ debulking of the enhancing tumour (glioblastoma, WHO grade IV) and the right subdural evacuation.

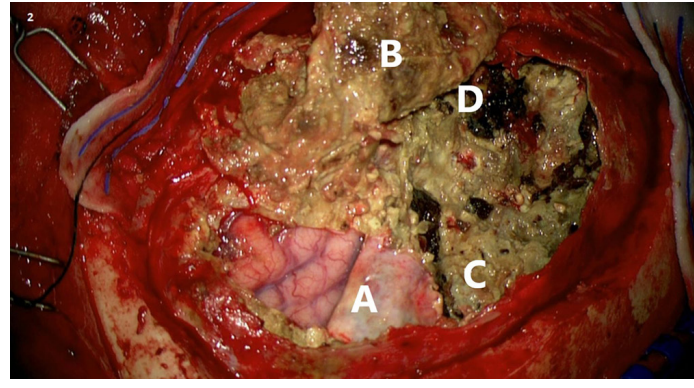

Figure 2 Intraoperative image taken after the right fronto-temporal-parietal craniotomy, dural opening and partial evacuation of the chronic highly calcified multilayer subdural haematoma. It shows $(A)$ the right inferior frontal lobe before tumour resection, (B) external subdural membrane, (C) internal subdural membrane and (D) the remaining chronic calcified subdural collection.

the symptoms caused by the glioma, the extensively calcified haematoma may not have been discovered 40 years after the insertion of his VP shunt.

\section{Learning points}

- Overdrainage of ventriculo-peritoneal shunts may cause non-traumatic subdural haematomas.

- Chronic subdural haematomas may be asymptomatic for many years.

Contributors ZW-YC was involved in drafting the manuscript and getting consent from the next of kin. PG was involved in conception, revising the manuscript and final approval of the version published. Both parties agree to be accountable for the article and to ensure that all questions regarding the accuracy or integrity of the article are investigated and resolved. Both parties contributed to the revision of the original article after reviewer's suggestions.

Funding The authors have not declared a specific grant for this research from any funding agency in the public, commercial or not-for-profit sectors.

Competing interests None declared.

Patient consent Next of kin consent obtained.

Provenance and peer review Not commissioned; externally peer reviewed.

(c) BMJ Publishing Group Ltd (unless otherwise stated in the text of the article) 2018. All rights reserved. No commercial use is permitted unless otherwise expressly granted.

\section{REFERENCES}

1 Merkler AE, Ch'ang J, Parker WE, et al. The rate of complications after ventriculoperitoneal shunt surgery. World Neurosurg 2017;98:654-8

2 Pappamikail L, Rato R, Novais G, et al. Chronic calcified subdural hematoma: case report and review of the literature. Surg Neurol Int 2013;4:21. 
Copyright 2018 BMJ Publishing Group. All rights reserved. For permission to reuse any of this content visit http://group.bmj.com/group/rights-licensing/permissions.

BMJ Case Report Fellows may re-use this article for personal use and teaching without any further permission.

Become a Fellow of BMJ Case Reports today and you can:

- Submit as many cases as you like

- Enjoy fast sympathetic peer review and rapid publication of accepted articles

Access all the published articles

- Re-use any of the published material for personal use and teaching without further permission

For information on Institutional Fellowships contact consortiasales@bmjgroup.com

Visit casereports.bmj.com for more articles like this and to become a Fellow 